\title{
Groundwater and marine intertidal Tubificidae (Oligochaeta) from the Canary and Cabo Verde Islands, with descriptions of two new species*
}

\author{
Christer Erséus \\ Department of Invertebrate Zoology, Swedish Museum of Natural History, Box 50007, S-104 05 \\ Stockholm, Sweden
}

Keywords: Oligochaeta, Tubificidae, taxonomy, Canary Islands, Cabo Verde Islands, biogeography, groundwater fauna

\begin{abstract}
Seven species of Tubificidae are recorded from the Canary Islands, viz. Heterodrilus amplus n. sp., Coralliodrilus leviatriatus Erséus, 1979, Limnodriloides agnes Hrabě, 1967, L. janstocki n. sp., Aktedrilus cuneus Erséus, 1984, A. parvithecatus (Erséus, 1978), and Tubifex tubifex (Müller, 1774); the two latter taxa are reported also from the Cabo Verde Islands. All taxa except $T$. tubifex are marine and there is no evidence of endemism in the freshwater oligochaete fauna of these islands. Heterodrilus amplus has short, spindle-shaped, heavily muscular atria; they are morphologically unique within the genus. Limnodriloides janstocki has modified spermathecal setae; it is distinguished from similar species by its long atrial ducts and deep, elaborate copulatory sacs.
\end{abstract}

\section{Résumé}

Sept espèces de Tubificidae sont signalées des îles Canaries, à savoir Heterodrilus amplus n. sp., Coralliodrilus leviatriatus Erséus, 1979, Limnodriloides agnes Hrabě, 1967, L. janstocki n. sp., Aktedrilus cuneus Erséus, 1984, A. parvithecatus (Erséus, 1978) et Tubifex tubifex (Müller, 1774); ces deux derniers taxa sont aussi signalés des îles du Cap Vert. Tous ces taxa - à l'exception de $T$. tubifex - sont marines, et aucun Oligochète endémique n'a été signalé dans les eaux douces de ces îles. Heterodrilus amplus possède des atria musculaires robustes, fusiformes particularité morphologique unique dans ce genre. Limnodriloides janstocki possède des soies spermathécales modifiées, et se distingue d'espèces semblables par ses longs conduits atriaux et par ses sacs copulateurs profonds et complexes.

\section{Introduction}

Among oligochaetes from groundwater habitats in the Canary and Cabo Verde Islands, collected in 1985-1987 by Prof. J.H. Stock (Institute of Taxonomic Zoology, University of Amsterdam), seven species of Tubificidae were found. All, except $T u$ bifex tubifex (Müller, 1774), are marine taxa, although the salinities of their habitats are mostly lower than that of seawater.

After collecting by hand, the samples were instantly preserved in $1 \%$ formalin and transferred into $70 \%$ alcohol within 24 hours. The tubificid specimens were stained in paracarmine, mounted whole in Canada balsam, and studied with a light microscope. The material is deposited in the Zoölogisch Museum of the University of Amsterdam (ZMA), Amsterdam.

\section{Taxonomy}

\section{Subfamily RHYACODRILINAE}

Heterodrilus amplus n. sp. (Fig. 1)

Holotype. - ZMA 2866, whole-mounted specimen from station 87/19: Canary Islands, Tenerife, Punta del Hidalgo, mediolittoral sand and gravel (coll. 17 April 1987 by J.H. Stock). Paratypes. - ZMA 2867.1 to 2867.7, 7 specimens from the same locality.

\footnotetext{
* Stygofauna of the Canary Islands, 25
} 

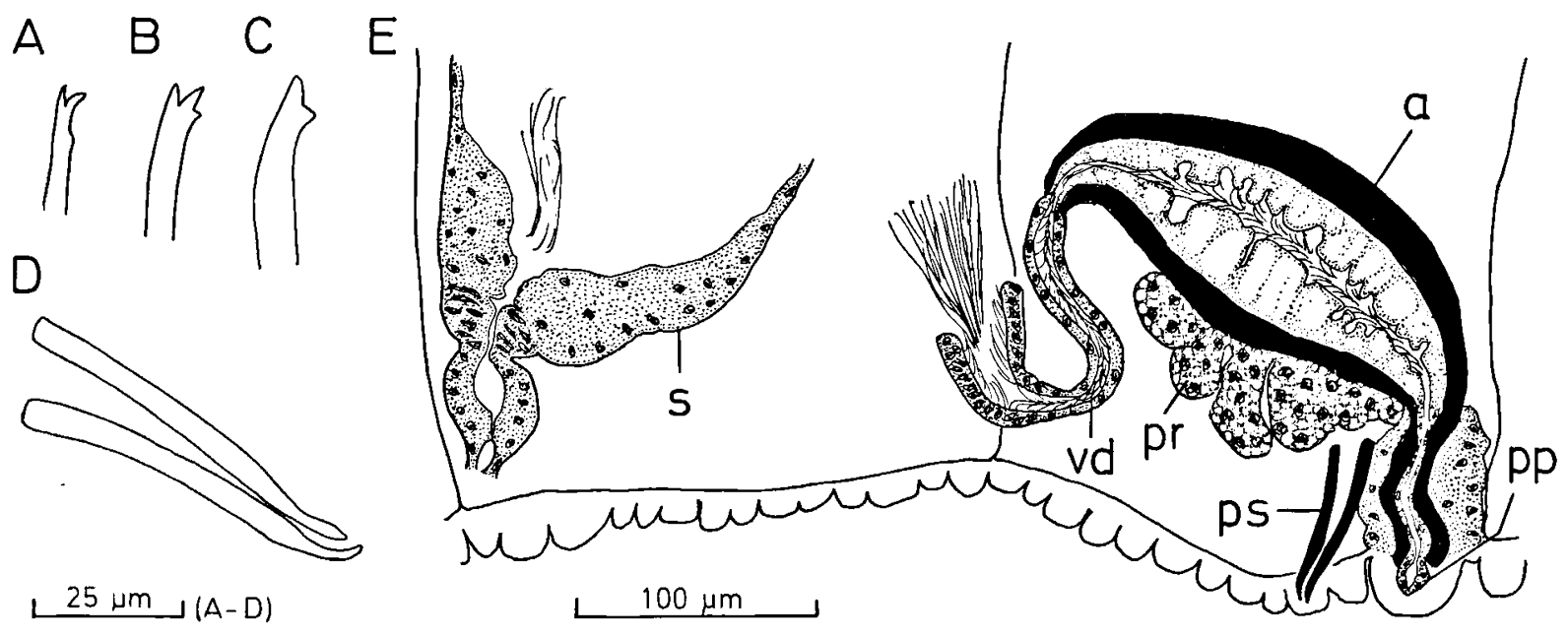

Fig. I. Heterodrilus amplus n. sp., holotype: A, seta of segment II; B, seta of segment VI; C, seta of postclitellar segment; D, penial setae; E, lateral view of spermatheca (part) and male genitalia in segments X-XI; a, atrium; pp, pseudopenis; pr, prostate gland; ps, penial seta; s, spermatheca; vd, vas deferens.

Etymology. - The epithet amplus ( = Latin, broad) refers to the great width of this species.

Description. - Length (6 complete specimens) 7.3-10.4 mm, 53-63 segments. Width at clitellum 0.58-0.78 $\mathrm{mm}$. Prostomium rounded, generally somewhat shorter than wide (preserved specimens). Clitellum extending over segments XI-XII. Somatic setae 2 per bundle in segments II-IX, 1 per "bundle" from segment X to posterior end. Anterior setae trifid, 75-150 $\mu \mathrm{m}$ long, 3.5-7 $\mu \mathrm{m}$ thick, those in segments II-III (Fig. 1A) with lowest tooth indistinct and "dislocated" down setal shaft, those in segments IV-IX (Fig. 1B) with all three teeth in ectal position, middle tooth being longest. Posterior setae (from segment $\mathrm{X}$ to posterior end of worm) bifid, with diverging, broad teeth (Fig. 1C); these setae being 90-135 $\mu \mathrm{m}$ long and 4.5-9 $\mu \mathrm{m}$ thick. Penial setae (Fig. 1D; ps in Fig. 1E) single-pointed or (in 2 specimens at least) trifid, somewhat sigmoid, 55-70 $\mu \mathrm{m}$ long, 3.5-5 $\mu \mathrm{m}$ thick, 2 (occasionally 1) per bundle; within bundle tips of setae closer to each other than are inner ends. Male pores paired, somewhat ventral to lines of ventral (somatic) setae, posteriorly in segment XI. Spermathecal pores paired, in line with ventral setae, in most anterior part of segment $\mathrm{X}$.

Pharyngeal glands in segments IV-VI. Granu- lated coelomocytes numerous. Male genitalia (Fig. 1E) paired. Vas deferens $16-20 \mu \mathrm{m}$ wide, shorter than atrium, entering (curved) apical end of atrium. Atrium with spindle-shaped, heavily muscular ampulla and narrower, less muscular duct. Atrial ampulla 195-235 $\mu \mathrm{m}$ long, $75-90 \mu \mathrm{m}$ wide, with muscular layer 11-16 $\mu \mathrm{m}$ thick, and with ciliated, and irregular, inner epithelium. Lobed prostate gland attached to ventral surface of atrial ampulla. Atrial duct much shorter than ampulla, surrounded by bulbous mass of tissue and ending in minute, simple pseudopenis (a small papilla-like structure; see pp in Fig. 1E). Spermathecae ( $s$ in Fig. 1E) consisting of distinct, somewhat bulbous ducts (with vestibules?) and large ampullae; walls of outer parts of ampullae generally thicker than those of inner parts. Sperm as random masses in spermathecae.

Remarks. - The atria of Heterodrilus amplus are morphologically unique within the genus. In the Northwest Atlantic $H$. perkinsi Erséus, 1986, the atrial muscles are of the same thickness as in $\mathrm{H}$. amplus, but the atria of $H$. perkinsi are extremely long and convoluted (see Erséus, 1986: fig. 5D). The penial setae are nearly similar in $H$. amplus and $H$. perkinsi, but the somatic setal pattern differs considerably. Heterodrilus perkinsi is not necessarily the closest relative of the new species. 
The anterior setae of $H$. amplus (Figs. 1A-B) are most similar to those of $H$. maccaini Erséus, 1985 and $H$. maiusculus Erséus, 1988, both from the Persian Gulf. These two latter taxa and $H$. amplus (as well as $H$. perkinsi in fact) have the male pores in a position ventral to the lines of the ventral setae, a supposedly apomorphic feature. Furthermore, the terminal parts of the atria (ducts and pseudopenes) are similar in $H$. amplus and $H$. maiusculus, whereas the short vasa deferentia (a plesiomorphy?) are shared by $H$. amplus and $H$. maccaini, as well as $H$. perkinsi. Thus, regardless of the possible relationships with these other species, $H$. amplus is clearly recognizable as a separate, new taxon.

Distribution and habitat. - Known only from the type locality on the Canary Island Tenerife. Intertidal sand.

\section{Subfamily PHALLODRILINAE}

\section{Aktedrilus cuneus Erséus, 1984}

Aktedrilus cuneus Erséus, 1984a: 193-195, fig. 1; 1987a: 111-114, figs. 2-3.

Material. - ZMA 2868, 1 specimen from station 87/09: Canary Islands, Isla de la Palma, Charco Verde ( = S. of Puerto Naos), mineral spring, temperature $22.3^{\circ} \mathrm{C}$, electric conductivity 6.76 $\mathrm{mS} / \mathrm{cm}$ (salinity about $4 \mathrm{ppt}$ ) (coll. 9 April 1987 by J.H. Stock).

Remarks. - Although some details in the genitalia are not clearly visible in this single specimen, it has small, comma-shaped atria, wedge-shaped, pendent penes, and glandular pads associated with the copulatory sacs, features characterizing $A$. cuneus. This species has been reported to show great variation in size (Erséus, 1987a: length 2.1-4.0 mm, 35-49 segments); although somewhat damaged, the present individual is about $2.8 \mathrm{~mm}$ long with only about 26 segments.

All previous records of $A$. cuneus are from marine intertidal habitats. The present record from a mineral spring with low salinity is therefore noteworthy.

Distribution and habitat. - Canary Islands (new record), Italy, Saudi Arabia, Galápagos Islands; apparently circumglobal. Marine intertidal and slightly salty underground spring water.

\section{Aktedrilus parvithecatus (Erséus, 1978)}

Bacescuella parvithecata Erséus, 1978: 264-265, fig. 2, table I; 1980: 106-107, fig. 10B; 1984a: 195-196; Erséus \& CantúMartinez, 1984: 183-184, fig. 2.

Bacescuella pilicrepus Erséus, 1984b: 153-154, fig. 11.

Aktedrilus parvithecatus; Erséus, 1987a: 117-119, fig. 6; 1990a 281; 1990b: 265.

Material. - ZMA 2869.1 and 2869.2, 2 specimens from station 87/119: Canary Islands, Fuerteventura, mouth of Barranco de los Molinos, gravel barrier, temperature $24.2^{\circ} \mathrm{C}$, electric conductivity $12.6 \mathrm{mS} / \mathrm{cm}$ (salinity about $7.5 \mathrm{ppt}$ ) (coll. 9 May 1987 by J.H. Stock).

ZMA 2870, 1 specimen from station 86/51: Cabo Verde Islands, Ilha do Sal, well at Algodocira, electric conductivity 17.04 $\mathrm{mS} / \mathrm{cm}$ (salinity about $11 \mathrm{ppt}$ ) (coll. 19 January 1986 by J.H. Stock).

Remarks. - This widespread, largely marine intertidal species is here reported from brackish water habitats on both the Canary and Cabo Verde Islands. The two individuals from Fuerteventura are 4.8 and $5.5 \mathrm{~mm}$ long, with 45 and 48 segments, respectively, the one from Ilha do Sal measures 4.8 $\mathrm{mm}$, with 48 segments. The specimens from Fuerteventura, however, have a less developed spermatheca than the one from Ilha do Sal. Therefore, the somewhat tentative identification of the Canarian specimens is solely based on the shape of the atria (long, cylindrical) and the penes (rounded triangular) (see Erséus, 1987a). The specimen from Cabo Verde bears one external spermatophore, which is characteristic of postcopulatory individuals of $A$. parvithecatus (see Erséus, 1987a: fig. 6).

Distribution and habitat. - Canary and Cabo Verde Islands (new records), France, Bermuda, Belize, Guadeloupe, Pacific coast of Mexico, Galápagos Islands, Hong Kong, and Saudi Arabia. Previously known from intertidal and barely subtidal sand; here reported from near-coastal and underground brackish waters (salinity 7.5-11 ppt). 

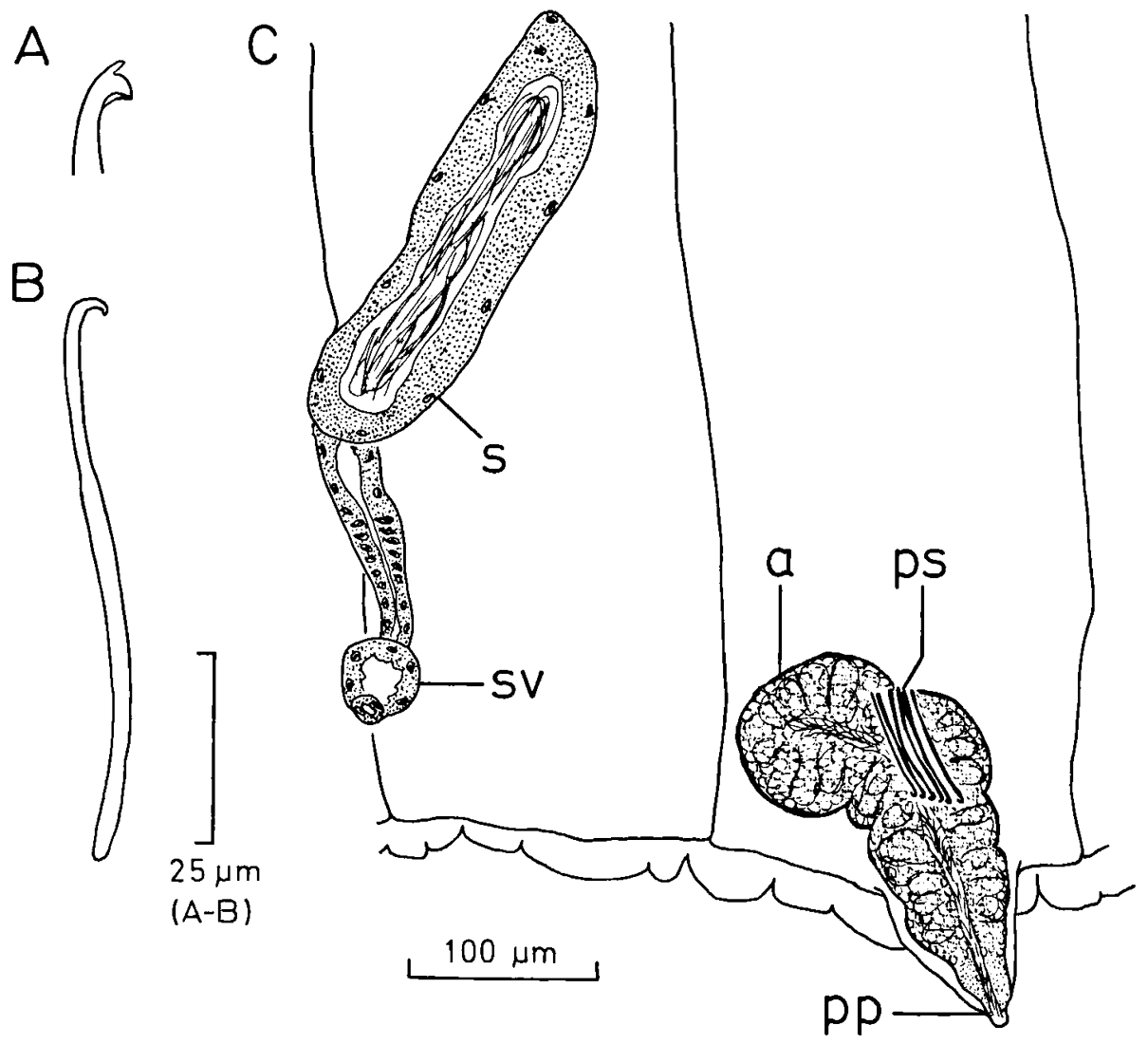

Fig. 2. Coralliodrilus leviatriatus Erséus, 1979, from Tenerife: A, somatic seta; B, penial seta; C, lateral view of genitalia in segments $\mathrm{X}-\mathrm{XI}$; a, atrium; pp, pseudopenis; ps, penial seta; s, spermatheca; sv, spermathecal vestibule.

\section{Coralliodrilus leviatriatus Erséus, 1979 (Fig. 2)}

Coralliodrilus leviatriatus Erséus, 1979: 179-180, fig. 1.

Material. - ZMA 2871.1 to $2871.6,6$ specimens from station 87/19: Canary Islands, Tenerife, Punta del Hidalgo, mediolittoral sand and gravel (coll. 17 April 1987 by J.H. Stock).

Description of new material. - Length 8.9-10.0 $\mathrm{mm}, 56-60$ segments. Width at clitellum (mounted specimens) $0.52-0.67 \mathrm{~mm}$. Prostomium short, rounded. Secondary annulation of body wall not prominent. Clitellum generally extending over segments $1 / 2 \mathrm{X}-\mathrm{XII}$; in one aberrant specimen with anteriorly shifted genitalia, over segments $1 / 2 \mathrm{VIII}-\mathrm{X}$. Somatic setae (Fig. 2a) bifid, with upper tooth distinctly shorter and thinner than lower tooth, and with subdental ligaments. Bifid setae 50-75 $\mu \mathrm{m}$ long, 2.5-5 $\mu \mathrm{m}$ thick at node, (2)3 per bundle anteriorly, 2 per bundle in postclitellar segments. Penial setae (Fig. 2B; ps in Fig. 2C) straight or somewhat sigmoid, single-pointed, slightly narrowing ectal to nodes, with strongly hooked tips; these setae being 70-90 $\mu \mathrm{m}$ long, 2-2.5 $\mu \mathrm{m}$ thick, (5)6-9 per bundle. Male pores paired in line with ventral setae, generally in posterior part of segment XI (shifted to segment IX in one specimen). Spermathecal pores paired, lateral, in most anterior part of segment $X$ (shifted to segment VIII in one specimen).

Pharyngeal glands in segments (III)IV-VI. Male genitalia (Fig. 2C) paired. Vas deferens inconspicuous, about $13 \mu \mathrm{m}$ wide, somewhat coiled, shorter than atrium; observed in only one specimen. Atrium elongate, generally curved, 150-250 $\mu \mathrm{m}$ long, 60-85 $\mu \mathrm{m}$ wide, with slender (about $1 \mu \mathrm{m}$ thick) muscular lining, and thick, granulated and 
ciliated, inner epithelium. Prostate glands absent. Atrium terminating in simple copulatory sac; when everted, sac and ectal part of atrium forming pointed pseudopenis (pp in Fig. 2C). Spermathecae (s in Fig. 2C) with slender ducts, 95-150 $\mu \mathrm{m}$ long, 14-26 $\mu \mathrm{m}$ wide, and oval to cylindrical ampullae, 130-245 $\mu \mathrm{m}$ long, 50-110 $\mu \mathrm{m}$ wide. Spermathecal vestibules (sv in Fig. $2 \mathrm{C}$ ) of varying width (30-50 $\mu \mathrm{m}$ ); when poorly developed merely swellings on spermathecal ducts, when fully developed forming diverticula on these ducts. Spermathecal ampullae with thick walls, and containing masses of random sperm.

Remarks. - This species has not been found since the original description of the Bermudian specimens collected in clearly subtidal habitats (Erséus, 1979). The newly recorded specimens from Tenerife are stouter and have fewer penial setae (mostly 9-11 of these setae per bundle in worms from Bermuda), but otherwise they conform well to the original description.

Genital shifts, although posteriorly (not anteriorly as described above), were reported for some Bermudian specimens too. The spermathecal vestibules, situated as diverticula on the spermathecal ducts, are larger and more conspicuous in the original material (Erséus, 1979: fig. 1C); in most of the Canarian individuals the vestibules appear as minor swellings on the ducts. Another slight difference with the original material is found in the more elongate spermathecal ampullae.

Distribution and habitat. - Canary Islands (new record) and Bermuda. Intertidal and subtidal sand, to at least $9 \mathrm{~m}$ depth.

\section{Subfamily LIMNODRILOIDINAE}

\section{Limnodriloides agnes Hrabè, 1967}

Limnodriloides agnes Hrabě, 1967: 339-344, figs. 13-14; Erséus, 1984b: 168-169, fig. 22; 1987b: 76-77; 1990a: 298-299; 1990c: 76; Erséus et al., 1990: 115-116, fig. 4A-B.

Limnodriloides agnes agnes; Erséus, 1982: 243-245, figs. 22-23.

For other references, see Erséus, 1990c.
Material. - ZMA 2872.1 to 2872.3, 3 specimens from station 85/60: Canary Islands, Lanzarote, anchihaline pool at foot of Montaña Bermeja, about $350 \mathrm{~m}$ from the sea, electric conductivity $38.4 \mathrm{mS} / \mathrm{cm}$ (salinity about $26 \mathrm{ppt}$ ) (coll. 16 May 1985 by J.H. Stock).

Remarks. - Only two of the present specimens are complete; they are 9.8 and $12.2 \mathrm{~mm}$ long, both with 68 segments. The largest of them is the longest individual of $L$. agnes so far reported; the previously noted length range was $4.3-10 \mathrm{~mm}$, with 33-68 segments (Hrabě, 1967; Erséus, 1982; 1984b; Erséus et al., 1990).

This species has been found in various parts of the world, mostly in subtidal marine habitats. The present record from anchihaline waters about 350 $m$ from the sea, however, seems to support the observation of tolerance to low salinities in Western Australia (Erséus, 1990c).

Distribution and habitat. - Canary Islands (new record), Black and Mediterranean Seas, China, southwestern Australia. Intertidal and subtidal (to at least $6 \mathrm{~m}$ depth), often muddy, sands. Brackish water and marine.

Limnodriloides janstocki n. sp. (Fig. 3)

Holotype. - ZMA 2873, whole-mounted specimen from station 86/503R: Canary Islands, Tenerife, salty well near beach of Bajamar, electric conductivity $34.6 \mathrm{mS} / \mathrm{cm}$ (salinity $27 \mathrm{ppt}$ ) (coll. 23 November 1986 by J.H. Stock).

Paratype. - ZMA 2874, whole-mounted specimen (fixation poor) from station 86/504R (another well on beach close to type locality), salinity about $2 \mathrm{ppt}$ (coll. 25 October 1986 by J.H. Stock).

Etymology. - Named after Dr. Jan H. Stock, Professor emeritus of Systematic and Geographic Zoology at the University of Amsterdam, who collected the material.

Description. - Holotype $10.3 \mathrm{~mm}$ long, with 75 segments (contracted specimen). Paratype about 23 mm long, about 90 segments (less contracted than holotype, but much coiled). Width at segment XI (compressed specimens) $0.62-0.68 \mathrm{~mm}$. Clitellum extending over segments XI-XII. Somatic setae 


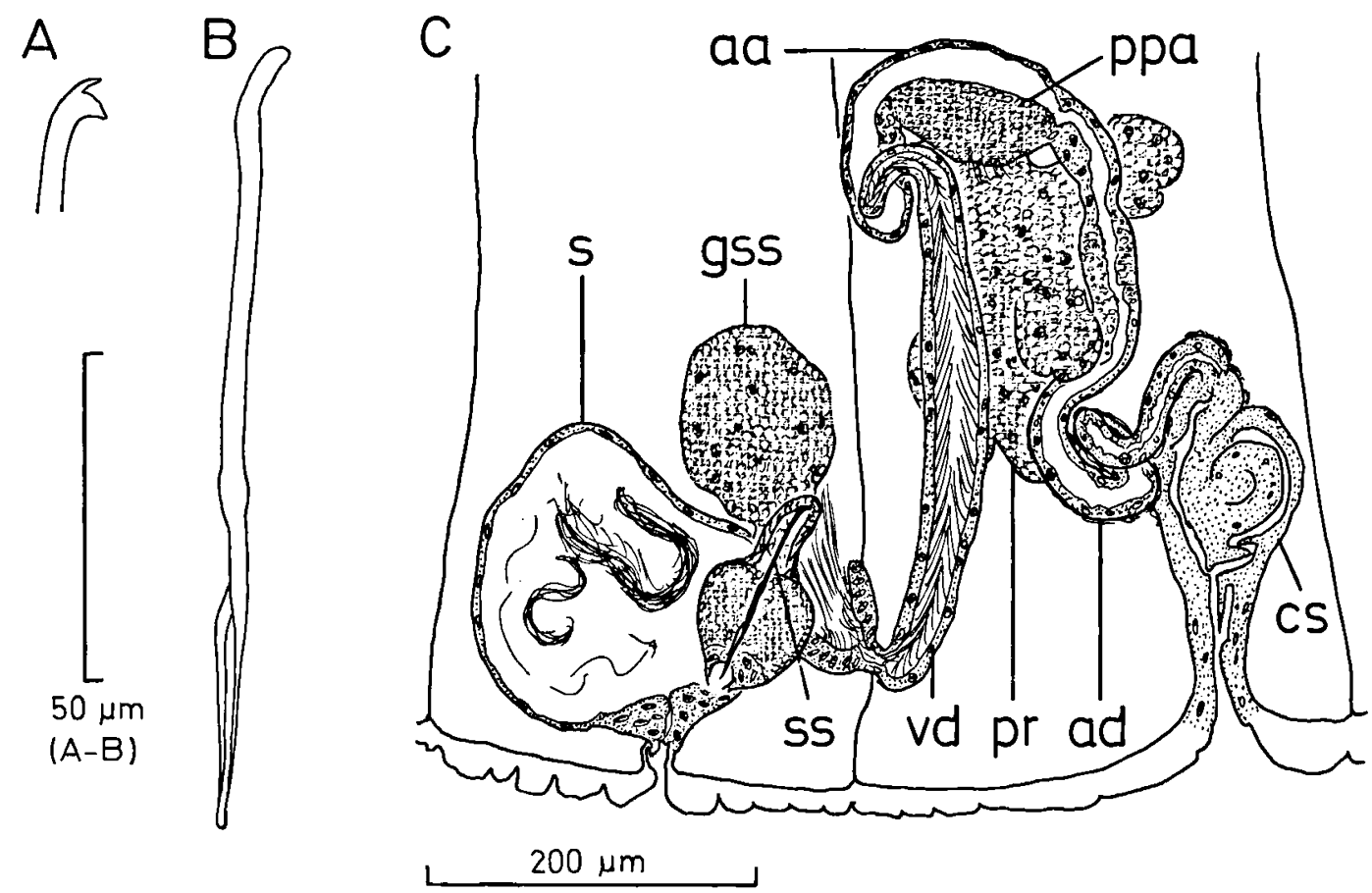

Fig. 3. Limnodriloides janstocki $\mathrm{n}$. sp., holotype: A, somatic seta; B, spermathecal seta; C, lateral view of genitalia in segments X-XI; aa, atrial ampulla; ad, atrial duct; cs, copulatory sac; gss, gland associated with spermathecal seta; ppa, prostatic pad; pr, prostate gland; s, spermatheca; ss, spermethecal seta; vd, vas deferens.

(Fig. 3A) bifid with upper tooth shorter and much thinner than lower tooth. Bifid setae 55-85 $\mu \mathrm{m}$ long, 2.5-4 $\mu \mathrm{m}$ thick, (2)3-4 per bundle anteriorly, 2 per bundle in postclitellar segments. Ventral setae of segment $X$ modified into spermathecal setae (Fig. 3B; ss in Fig. 3C), one at each side, immediately posterior to spermathecal pores. Spermathecal setae single-pointed, about $120 \mu \mathrm{m}$ long, 2.5-3 $\mu \mathrm{m}$ thick, with ectal $1 / 3$ grooved and somewhat twisted; outer part of each seta enclosed in roundish, glandular sac, latter bearing an external gland (gss in Fig. 3C). Ventral setae of segment XI absent. Male pores paired, very close together ventrally, in posterior part of segment XI. Spermathecal pores paired, very close together ventrally, in middle of segment $X$.

Pharyngeal glands in segments IV-V. Oesophageal diverticula in segment IX moderately large. Male genitalia (Fig. 3C) paired. Vas deferens somewhat shorter than atrium, up to $35 \mu \mathrm{m}$ wide and with wide lumen for most part, entering atrial ampulla subapically. Atrial ampulla about $200 \mu \mathrm{m}$ long and about $70 \mu \mathrm{m}$ wide, slightly curved, with conspicuous prostatic pad filling a large part of ectal half of ampulla. Prostate gland large, lobed. Muscular lining of ampulla distinct, but nowhere thicker than about $2 \mu \mathrm{m}$. Atrial duct more than $2 \times$ longer than ampulla, up to about $30 \mu \mathrm{m}$ wide; ental part not as densely granulated as typical of the genus, but this may be due to poor fixation. Atrial duct ectally coiled and terminating in complex, very deep, copulatory sac; details of latter, however, not clear in available material (outline of inner folding is somewhat schematic in Fig. 3C), but a globular papilla-like structure appears to be present inside the sac. Spermathecae (s in Fig. 3C) with indistinct, very short ducts, and large, thin-walled ampullae; sperm partly arranged in bundles $(=$ spermatozeugmata?; fixation poor) in ampullae.

Remarks. - This species resembles the marine $L$. australis Erséus, 1982, known only from shallowwater coral sands on the Great Barrier Reef. Limnodriloides janstocki is distinguished by its much 
longer atrial ducts and deeper and more elaborate copulatory sacs. In $L$. australis, the ducts are only slightly longer than the atrial ampullae and the copulatory sac is partly unpaired with two small "compartments" receiving the ducts. In addition, there are maximally 3 or 4 setae per (anterior) bundle in the new species, versus only 2 setae per bundle in $L$. australis, although this difference, per se, should perhaps not be regarded as specific, considering the wide geographic separation.

Distribution and habitat. - Known only from Bajamar on Tenerife (E. Atlantic). Although the material was collected in two wells, the high salinity and the proximity to the sea of at least one of these, as well as the biology of all the other species in the genus, indicate that this species may be expected to occur also in open marine or brackish-water habitats.

\section{Subfamily TUBIFICINAE}

Tubifex tubifex (Müller, 1774)

For references, see Brinkhurst, 1971: 453-455; and Holmquist, 1983: 189-192, figs. 1-3.

Material. - ZMA 2875.1 to 2875.6, 6 specimens from station 86/525: Canary Islands, Tenerife, Playa Paraiso, sand and gravel in distribution station for canalized water, electric conductivity $975 \mu \mathrm{S} / \mathrm{cm}$ (salinity about $0.7 \mathrm{ppt}$ ) (coll. 9 November 1986 by J.H. Stock).

ZMA 2876.1 and 2876.2, 2 specimens from station 86/35: Cabo Verde, São Tiago, well at Ponta Verda, electric conductivity $2.44 \mathrm{mS} / \mathrm{cm}$ (salinity about $1.7 \mathrm{ppt}$ ) (coll. 16 January 1986 by J.H. Stock).

Remarks. - Many taxa are regarded as junior synonyms of Tubifex tubifex (Müller, 1774) (cf. Brinkhurst, 1971), although Holmquist (1983), who redescribed and selected a neotype of this species, has recommended a more restricted diagnosis. The genitalia of the present material from the Canary and Cabo Verde Islands conform to Holmquist's description, but some of the specimens from Tenerife as well as both from Cabo Verde have hair setae that are neither as many nor as large as is typical of $T$. tubifex (sensu stricto).
This widespread, largely freshwater, species occurs also in oligohaline brackish-water habitats. Chapman \& Brinkhurst (1987) have shown experimentally that if exposed to salinities of $1 \mathrm{ppt}$ or more, $T$. tubifex tends to loose some or all of the hair setae and the pectination of the dorsal crotchets, and thus becomes what has been regarded as the "bergi" form, a taxon originally described by Hrabě (1935) and regarded as a separate species by Holmquist (1983) as well. Some of the present specimens thus conform to the "bergi" form, at least in terms of hair setae. The disappearance of some hairs is probably explained by the presence of salt (about 0.7-1.7 ppt) in the habitat.

Distribution and habitat. - Largely cosmopolitan. In various freshwater and oligohaline habitats.

\section{Discussion}

In the Canary Islands the following tubificid species occur: Heterodrilus amplus, Aktedrilus cuneus, $A$. parvithecatus, Coralliodrilus leviatriatus, Limnodriloides agnes, Limnodriloides janstocki, and Tubifex tubifex. From the Cabo Verde Islands only two species are recorded: Aktedrilus parvithecatus and Tubifex tubifex.

Six of the species treated in the present study can be considered as marine, although some of them have now been collected in anchihaline or brackishwater habitats. Aktedrilus cuneus, A. parvithecatus, and Limnodriloides agnes are known from all major oceans; they are most certainly circumglobal, whereas Coralliodrilus leviatriatus is at least amphi-Atlantic, being recorded from Bermuda as well. The two new species, Heterodrilus amplus and Limnodriloides janstocki, are known from the Canary Islands only.

The widely distributed Tubifex tubifex is the only tubificid so far recorded from freshwater (or oligohaline) habitats of the Canary and Cabo Verde Islands. Grimm (1978), who studied Oligochaeta of the irrigation water-system of Tenerife (Canary Islands), reported twelve identified species of Naididae that are either cosmopolitan or distributed throughout the tropics. There is thus still no evi- 
dence of endemic elements in the aquatic oligochaete fauna of these oceanic islands, a statement that holds true for the Azores and Madeira as well (Brinkhurst, 1969).

\section{Acknowledgements}

I am indebted to Prof. Jan H. Stock for making this interesting collection available to me and for critically reviewing the manuscript; to Drs. Ronald Vonk (University of Amsterdam) for additional information; to Ms. Barbro Löfnertz (University of Göteborg) and Ms. Christine Hammar (Swedish Museum of Natural History) for technical assistance; and to the Swedish Natural Science Research Council for financial support.

\section{References}

Brinkhurst, R.O., 1969. Aquatic Oligochaeta of the Azores and Madeira. Bolm. Mus. munic. Funchal, 23: 46-48.

Brinkhurst, R.O., 1971. Family Tubificidae. In: R.O. Brinkhurst \& B.G.M. Jamieson (eds.), Aquatic Oligochaeta of the world: 444-625 (Oliver \& Boyd, Edinburgh).

Chapman, P.M. \& R.O. Brinkhurst, 1987. Hair today, gone tomorrow: induced chaetal changes in tubificid oligochaetes. Hydrobiologia, 155: 45-55.

Erséus, C., 1978. Two new species of the little-known genus Bacescuella Hrabe (Oligochaeta, Tubificidae) from the North Atlantic. Zoologica Scr., 7: 263-267.

Erséus, C., 1979. Coralliodrilus leviatriatus gen. et sp. n., a marine tubificid (Oligochaeta) from Bermuda. Sarsia, 64: 179182.

Erséus, C., 1980. Taxonomic studies on the marine genera Aktedrilus Knöllner and Bacescuella Hrabě (Oligochaeta, Tubificidae), with descriptions of seven new species. Zoologica Scr., 9: 97-111.

Erséus, C., 1982. Taxonomic revision of the marine genus Limnodriloides (Oligochaeta, Tubificidae). Verh. naturwiss. Ver. Hamburg (N.F.), 25: 207-277.

Erséus, C., 1984a. Interstitial fauna of Galapagos XXXIII. Tubificidae (Annelida, Oligochaeta). Microfauna marina, 1: 191-198.

Erséus, C., 1984b. The marine Tubificidae (Oligochaeta) of Hong Kong and Southern China. Asian mar. Biol., 1: 135175.

Erséus, C., 1985. Annelida of Saudi Arabia. Marine Tubificidae
(Oligochaeta) of the Arabian Gulf coast of Saudi Arabia. Fauna Saudi Arabia, 6 “1984": 130-154.

Erséus, C., 1986. Marine Tubificidae (Oligochaeta) at Hutchinson Island, Florida. Proc. biol. Soc. Wash., 99: 286-315.

Erséus, C., 1987a. Taxonomic revision of the marine interstitial genus Aktedrilus (Oligochaeta, Tubificidae), with description of three new species. Stygologia, 3: 107-124.

Erséus, C., 1987b. A new species of Phallodrilus and records of two other marine Tubificidae (Oligochaeta) from the Mediterranean coast of Israel. Isr. J. Zool., 22 “1984/85”: 73-78.

Erséus, C., 1988. Marine Tubificidae (Oligochaeta) of the Arabian Gulf coast of Saudi Arabia (Part 4). Fauna Saudi Arabia, 9: 19-22.

Erséus, C., 1990a. Marine Oligochaeta of Hong Kong. In: B. Morton (ed.), Proceedings of the Second International Marine Biological Workshop: The marine flora and fauna of Hong Kong and southern China, Hong Kong, 1986, Vol. 1: 259-335 (Hong Kong University Press, Hong Kong).

Erséus, C., 1990b. The marine Tubificidae (Oligochaeta) of the barrier reef ecosystems at Carrie Bow Cay, Belize, and other parts of the Caribbean Sea, with descriptions of twenty-seven new species and revision of Heterodrilus, Thalassodrilides and Smithsonidrilus. Zoologica Scr., 19: 243-303.

Erséus, C., 1990c. The marine Tubificidae and Naididae (Oligochaeta) of Southwestern Australia. In: F.E. Wells, D.I. Walker, H. Kirkman \& R. Lethbridge (eds.), Proceedings of the Third International Marine Biological Workshop: The marine flora and fauna of Albany, Western Australia, Vol. 1: 43-88 (Western Australian Museum, Perth).

Erséus, C. \& P.C. Cantú-Martinez, 1984. A new record of Bacescuella parvithecata (Oligochaeta, Tubificidae) from Golfo de California. Sarsia, 69: 183-184.

Erséus, C., Sun Daoyuan, Liang Yanling \& Sun Bin, 1990. Marine Oligochaeta of Jiaozhou Bay, Yellow Sea coast of China. Hydrobiologia, 202: 107-124.

Grimm, R., 1978. Die Fauna des Bewässerungssystems der Insel Teneriffa unter besonderer Berücksichtigung der Naididae (Oligochaeta). Zool. Anz., 201: 143-150.

Holmquist, C., 1983. What is Tubifex tubifex (O.F. Müller) (Oligochaeta, Tubificidae)? Zoologica Scr., 12: 187-201.

Hrabe, S., 1935. Die Oligochaeten des Issykkulsees. Trudy kirgiz. kompleks. Eksped., 3: 73-85.

Hrabě, S., 1967. Two new species of the family Tubificidae from the Black Sea, with remarks about various species of the subfamily Tubificinae. Spisy prirodoved. Fak. Univ. Brne, 485: 331-356.

Müller, O.F., 1774. Vermium terrestrium et fluviatilium, 1(2): 1-72 (Heineck et Faber, Havniæ et Lipsiæ).

Received: 5 March 1992 